\title{
Shifting Patterns in Developmental Rank Ordering: A Case Study of the Districts of Sind Province
}

\author{
HAROON JAMAL and SALMAN MALIK*
}

\begin{abstract}
The primary objective of this paper is to observe the changing patterns in regional development and to highlight some of the major underlying phenomena. Our examination of changes in rank ordering over a short period of time reveals that only moderately developed districts have altered their position in either upward or downward direction. Larkana district moved from sixth to fourth rank, while Tharparkar district regressed considerably from fourth to eighth rank. The exercise will facilitate policy-makers in allocating development resources in districts where the deficiencies are evidently serious. It will also be helpful in locating research areas to determine particular bottlenecks to development in districts which shifted downward in rank ordering.
\end{abstract}

\section{INTRODUCTION}

The decade of the 70s has witnessed efforts by various national and provincial governments in Pakistan to reduce regional disparities in the level of development. A number of explicit spatial policies have been pursued towards this objective. These have included, on the one hand, a range of fiscal and monetary incentives ${ }^{1}$ to industrial investment in backward areas and mandatory restrictions, ${ }^{2}$ on the other hand,

*The authors are Research Economist and Research Officer, respectively, at the Applied Economics Research Centre, University of Karachi. They are grateful to Dr Hafiz A. Pasha, for his substantive comments and help in finalizing the draft of this paper. They also thank Sajjad Akhtar and two anonymous referees for their valuable comments. Any defects which remain are,of course, the sole responsibility of the authors.

${ }^{1}$ To promote balanced regional development, general and/or region specific incentives are granted. For instance, complete exemption from customs duty is available on import of certain machinery and equipment in Shikarpur, Jacobabad, Tharparkar and Dadu (excluding Kotri). Industries in Hyderabad, Kotri and Karachi division, cannot avail this facility. In order to provide for timely credit in adequate quantities to different regions, mandatory credit targets have been given to the commercial banks. Tax holiday for industries in least developed areas is another example of region specific incentives.

${ }^{2}$ In Sind, there is a general ban on any new unit in Karachi, Dhabeji and Gharo, unless it can either only be established at these locations (ship-building and repairs, ship-breaking, sea sault, canning and preservation of sea food) or has downstream links with major investments like Steel Mill (engineering workshops) or has a localized market (ice and cold storage, bakeries) or represents the application of complex, large-scale technology (petrochemicals). 
on the establishment of new units in certain industries in the developed metropoli$\tan$ regions of the country like Karachi and Lahore. In addition, there has been a dimension of regional equity in the allocation of public expenditures on physical and social infrastructure. The changed sectoral emphasis, with higher priority on rural development, is likely also to have had some favourable consequences on the spatial distribution of national income and welfare.

The basic question that arises is the extent of progress that has been achieved as a result of these policies in reducing regional imbalances in the level of development at the district level in Pakistan. It is the objective of this paper to identify the shifting pattern in the development rank ordering over the $70 \mathrm{~s}$ in one province of the country, viz, Sind. This is a province which has traditionally been characterized by fairly sharp differences among districts in the level of development with the largest city of the country, Karachi, dominating economic activity in the province and the rest of the province being essentially rural and relatively underdeveloped, except for a few pockets of development in districts like Hyderabad and Sukkur.

The basic conceptual view of development adopted in this paper is to see it as the end result of interaction between various technological, economic, social and institutional factors. As such a series of indicators have been used to indirectly measure territorial levels of development [see Torgerson, Warren S. (1958)]. These indicators primarily relate to development inputs and can be used as tools for regional planning.

The paper has been organized as follows. Section II describes the particular indicators used for evolving the spatial and inter-temporal ranking of the districts of Sind in terms of level of development. Section III discusses the methodology used for combining the various indicators into one summary measure of the level of development. Section IV presents the results of the empirical analysis. In Section V, we highlight the major implications of the findings and indicate some of the limitations of the exercise. Finally, the Appendix to the paper describes the various data sources for the different indicators and includes the background tables to the study.

\section{CHOICE OF DEVELOPMENT INDICATORS}

A number of studies have been undertaken in the past to rank districts of Pakistan in terms of level of development. Helbock and Naqavi (1976) used a multidimensional approach to determine the relative level of development at the district level for the 60s. Pasha and Hasan (1984) have attempted a similar analysis for the 70s. Khan and Iqbal (1982) have used the most recent data from the Agricultural Census of 1980 , to quantify the spatial variation in the level of development of rural areas of the country in terms of access of villages to basic inputs and services.

All the above studies have, however, constructed development rankings at one moment in time. In this paper, given a consistent set of development indicators and data sources, an attempt is made to show how districts have changed their rank orderings over a period of ten years, from the early 70 s to the early 80 s.

Indicators that have been included in the study relate to measures of economic potential and achieved levels of income and wealth; mechanization and modernization of the rural sector, especially agriculture; housing standards and access to basic residential services; development of transport and communications; and availability of health and educational facilities. The individual indicators chosen are described below. Sources of data for the different indicators are described in Appendix (Table A-1).

\section{Income and Wealth}

Various indicators have been used for deriving the income and wealth position of a district. These indicators correspond to the traditional measures of the level of development. For the rural esonomy, agricultural value added per capita (AGVAD) is the basic indicator. It includes value added in major and minor crops, fishing and forestry. The method of computing the value added is, more or less, the same as adopted in national income accounts. Another important indicator of income and wealth in rural areas is live-stock per capita (LSTOCK). Different types of livestock have been aggregated by assigning weights. The extent of commercialization of agri. culture (CCROPS) has also been used as a proxy for the relative modernization and prosperity of a rural area. It represents the proportion of total cropped area being used for the cultivation of cash crops like cotton, sugar-cane, rice, etc.

For the urban component of a district, per capita manufacturing value added (MVAD) has been used as an indicator of income levels. Due to the paucity of data, only value added in the large-scale industrial sector has been considered. Therefore, this measure may create distortions in the case of districts which have a relatively high presence of small-scale establishments.

An overall measure, albeit crude, of wealth levels included in the study is the number of bank branches per 10,000 persons (Banks). The assumption is that there is a direct correlation between the number of branches and the volume of bank deposits in a district. This assumption may at least partially be violated in the case of districts which are geographically large and access to banking services for the dispersed population may imply, other things being equal, a bigger network of branches.

\section{Modernization of Agriculture}

There is some debate as to whether mechanization of agriculture confers net social benefits. On the one hand, it contributes to higher yields and greater farm income leading to a rise in the standard of living while, on the other hand, there is evidence that the use of tractors and other farm implements had led to tenant evictions, labour displacement and more skewed distribution of land holdings. However, an indicator of the extent of mechanization of agriculture in the form of 
tractors per 1000 acres of cropped area (TRACT) has been used in this paper to capture the process of modernization in the countryside. In addition, the extent of use of fertilizer, measured as consumption of fertilizer as proportion of cropped area (FERT), and access to canal irrigation systems and tube-wells, in terms of irrigated area as proportion of cropped area (IRRI), have also been used as indicators of modernization in farming practices.

\section{Housing Conditions}

Improvement in housing conditions is one of the important consequences of socio-economic development. Possible indicators in this sector include the proportion of households without homes, the proportion in 'Pucca' dwellings, access to toilets by type, water connections, electricity and gas, etc. Again availability of data has restricted the choice to three indicators, viz, proportion of households using electricity (ELECT), gas (GAS) and with inside water connection (WATER)

\section{Communications}

Number of Radio sets (RADIO) per 1000 population, Television sets (TV) and number of Post offices (POST) per 100,000 population have been taken as indicators of the access to media and development of communication facilities. Data on number of residential telephone connections (TELEP) were not directly available, on estimated in a manner described in the Appendix (Table A-4).

Development of the transportation network of a district has been seen in terms of metalled road mileage (MROAD) and unmetalled road mileage (UMROAD) per 100 square miles of geographical area. With regard to the availability of transport vehicles, the use of a summary measure, viz., passenger load carrying capacity per capita, was first suggested by Pasha and Hasan (1984). The same approach, with some modification, has been used in this paper. The aggregate measure has been broken up into two indicators primarily to indicate availability of transport for lower and upper income groups in a district. For the former, by using appropriate weights, the number of scooters, motorcycles, taxis, autorickshaws and buses per 1000 urban population (PASSEN) has been determined. For the latter, the measure is cars, jeeps and station wagons per 1000 urban population (CARS).

\section{Health}

A number of indicators of health conditions are discussed in the literature. However, district-wise statistics on indicators such as life expectancy at birth, infant mortality rate, maternal mortality rate, etc. are currently not available. Hence, indicators of inputs rather than outputs of health services were used to explain the development in this sector. These are, first, the number of beds in hospitals, dispensaries and rural health centres (BEDS) and, second, the number of doctors per 10,000 population (DOCTORS).

\section{Education}

One of the basic indicators of development is the literacy rate. However, this indicator could not be included in the analysis because of the difference in the definition of literacy in the population censuses of 1972 and 1981. Therefore, instead of a stock measure of the development of the education sector, indicators of flow of output were used. Gross enrollment as proportion of population in the relevant age group are defined for primary (PENR), middle level (MENR), higher secondary (HENR) and intermediate and degree college level (IDENR).

Further Teacher-school and Teacher-student ratios have been included to depict the quality of education. In both types of ratios, three levels viz., Primary (PTSC and PTST), Secondary and Matric (HTSC and HTST) and Inter Degree (IDTSC and IDTST) have been considered.

Altogether, the total number of indicators included in the study is 31 . There are five indicators of income and wealth, three of modernization of agriculture, three of housing conditions, eight of transport and communications, two of health and ten of education. ${ }^{3}$

\section{METHODOLOGY FOR RANKING DISTRICTS}

The simplest numerical procedure in establishing ranks of districts is the summation across indicators of standardized scores in each indicator. This technique is referred to as the $Z$-sum technique, and is described as follows:

$$
(Z \text {-sum })_{j}=\sum_{i=1}^{n}\left[\frac{X_{i j}-\bar{X}_{i}}{S_{i}}\right] \quad \ldots
$$

where

$$
\begin{aligned}
& n=\text { Number of indicators; } \\
& \bar{X}_{i}=\text { Mean value of } i \text { th indicator; } \\
& S_{i}=\text { Standard deviation of } i \text { th indicator; and } \\
& X_{i j}=\text { Value of } i \text { th indicator in } j \text { th district. }
\end{aligned}
$$

The higher the $Z$-sum for a particular district the more developed it is in relation to other districts. The basic problem with this technique is that it assigns equal weights to all indicators.

${ }^{3}$ An exercise to verify the sensitivity of ranks to the number of indicators in each sector yielded almost similar rank ordering. We ranked districts after standardizing for the number of indicators using $Z$-score in each sector (for instance, $Z$-sum in income and welath divided by 5 plus $Z$-sum in Housing divided by 3 and so on). The rank correlation coefficient in overall $Z$-sum (standardized for number of indicators by sector) and overall $Z$-sum (without standardizing sectors) was 0.97 for the year $1980-81$, while it was 0.92 for 1971-72. 
The concept of Taxonomic distance is also used for the purpose of ranking of countries or territorial units on the basis of selected indicators. This procedure establishes the difference between an 'ideal' unit and the observed unit. For our purpose, an 'ideal' district is one which has 'best' value for a particular indicator. After standardizing indicators, taxonomic distance is obtained using the following formula:

$$
(T D)_{j}=\left[\sum_{i=1}^{n}\left(Z_{i j}-\tilde{Z}_{i}\right)^{2}\right]^{1 / 2} \quad \ldots \quad \ldots
$$

where

$$
\begin{aligned}
& Z_{i j}=\text { Standardized value of } i \text { th indicator in } j \text { th district; and } \\
& \widetilde{Z}_{i}=\text { Highest standardized value of } i \text { th indicator among all districts: }
\end{aligned}
$$

The most developed district is one which has the minimum taxonomic distance. This technique also attaches equal weights to all indicators. In addition, the contribution to $T D$ by a particular indicator can be increased if its maximum value, $\widetilde{Z}_{i j}$, is very large in relation to the values for other districts. Therefore, this technique is sensitive to the presence of outliers. ${ }^{4}$ In fact, in the context of Sind, Karachi district has very large magnitudes for some indicators in relation to other districts. Therefore, this district has been dropped from the analysis in order to avoid biases in the derivation of taxonomic distances.

Another common and popular multivariate method for indexing level of socioeconomic development is the technique of factor analysis. ${ }^{5}$ This technique proceeds by clustering indicators which are correlated most into factors such that the latter is a linear combination of the former. In addition, it attempts to create factors which have minimum correlation among each other. Weights are assigned to each factor on the basis of eigen values, and in this manner the overall factor score for a district is computed.

Helbock and Naqavi (1976) and Pasha and Hasan (1984) have both used the $Z$-sum technique and factor analysis for ranking districts. Khan and Iqbal (1982) have, however, relied on the approach of taxonomic distances. In this study, the relatively simple techniques of $Z$-sum and taxonomic distances have both been used. The two procedures lead to almost identical ranks for the different districts in both time periods, thereby demonstrating the robustness of the results.

Due to the nature of the data set, factor analysis could not be used for ranking the districts. Bum (1982) has shown that spurious results may be obtained if the number of indicators is equal to or greater than the number of spatial units in the

${ }^{4}$ The technique of $Z$-sum is also sensitive (although less as compared with taxonomic distance) in case of outlier which effects the magnitude of the mean and standard deviation.

${ }^{5}$ For detailed discussion, [see Adelman and Morris (1972)] . analysis. The reason for this is fairly obvious. If there are more variables than observations, the relevant co-variance matrix will be singular and its inverse will not exist. Zerby and Khan (1984) have provided an empirical illustration of this problem. In this study, with 31 indicators and ten districts only, the factor analysis technique could not, therefore, be applied.

\section{EMPIRICAL FINDINGS}

Table 1 gives the magnitude of the $Z$-sum and Taxonomic distance in 1971-72 and 1980-81 for the ten districts of Sind included in the study. There appears to be considerable stability in the rankings of the most and least developed districts. Hyderabad, Sukkur and Khairpur have remained the three top districts of Sind (excluding Karachi) while Jacobabad and Thatta continue to be the most backward districts. There has been some change in ranking only among the intermediate districts. Larkana has demonstrated the greatest improvement followed by Dadu. On the other hand, Tharparkar has slipped considerably in its rank. Nawabshah and Sanghar have retained their relative position.

The robustness of the results is confirmed ${ }^{6}$ by the fact that the correlation in ranks according to the two techniques is very high in both years. In 1971-72 the rank correlation coefficient was 0.99 and in 1980-81, 0.96.

\begin{tabular}{|c|c|c|c|c|c|c|c|c|}
\hline \multirow{2}{*}{ Districts } & \multicolumn{4}{|c|}{$1971-72$} & \multicolumn{4}{|c|}{$1980-81$} \\
\hline & $Z$-sum & Rank & $\begin{array}{l}\text { Taxonomic } \\
\text { Distances }\end{array}$ & Rank & $Z$-sum & Rank & $\begin{array}{c}\text { Taxonomic } \\
\text { Distance }\end{array}$ & Rank \\
\hline Khairpur & 2.19 & 4 & 12.72 & 3 & 2.68 & 3 & 12.40 & 3 \\
\hline Jacobabad & -10.65 & 9 & 14.37 & 9 & -16.77 & 10 & 15.13 & 9 \\
\hline Sukkur & 10.72 & 2 & 10.89 & 2 & 15.06 & 2 & 10.74 & 2 \\
\hline Nawabshah & -7.78 & 7 & 13.70 & 7 & -5.94 & 6 & 13.60 & 7 \\
\hline Larkana & -6.51 & 6 & 13.42 & 6 & -1.56 & 5 & 12.73 & 4 \\
\hline Sanghar & -4.21 & 5 & 13.26 & 5 & -0.04 & 4 & 13.00 & 5 \\
\hline Tharparkar & 3.35 & 3 & 13.12 & 4 & -9.05 & 8 & 14.14 & 8 \\
\hline Dadu & -8.30 & 8 & 13.79 & 8 & -6.54 & 7 & 13.50 & 6 \\
\hline Hyderabad & 35.23 & 1 & 8.08 & 1 & 34.68 & 1 & 8.11 & 1 \\
\hline Thatta & -14.04 & 10 & 15.15 & 10 & -12.60 & 9 & 15.30 & 10 \\
\hline
\end{tabular}

Table 1

Magnitude of Z-sum and Taxonomic Distances

${ }^{6}$ Because of this robustness, we will present the remaining results based on taxonomic distance technique. 
Another important conclusion from Table 1 is that despite the various policy measures adopted, as mentioned earlier, regional disparities in the province of Sind have not tended to decline in the 70s. The evidence, at best, is ambiguous with respect to the change in the gap between the most and least developed districts. This is revealed by examining the change in taxonomic distances for each district over the period. Taxonomic distances have increased (implying reduction in the gap) somewhat for the two most developed districts, Hyderabad and Sukkur. However, they have increased significantly (implying increase in gap) for the two most backward districts, Thatta and Jacobabad. It is clear that a significant breakthrough has not yet been achieved in bringing the various districts of Sind closer to each other in terms of the level of development. ${ }^{\text {? }}$

To answer the question of regional disparities, explicitly, it is hypothesized that change in $Z$-score in each district for each variable is a function of base year's magnitude of $Z$-score. Using this regression specification, ${ }^{8} 31$ coefficients are estimated. The sign, magnitude and level of significance of $\beta$ 's are used to explain the changes in regional disparities over the time.

The important conclusions from this exercise are, first, all publicly provided municipal services - electricity, water and gas - have shown increase in disparity between most privileged and less privileged districts of Sind. This assertion is obtained from positive and significant coefficients (see Appendix, Table A-5). Second, inverse and significant coefficient of unmetalled road indicates that disparity has decreased in this development activity. Third, all negative coefficients in education has confirmed a general success of Government in terms of decreasing disparity among districts of Sind especially in primary education. Fourth, disparity among districts in modernization and mechanization of agriculture has, by and large, not altered. Fifth, it seems that disparities have decreased, to some extent, in per capita physicians availability. Finally, there appears no change in disparity in manufacturing value added. Thus it implies that fiscal and monetary incentives have not worked, properly, to decrease regional disparity in industrial investment.

Table 2 presents the sectoral ranks of each district in the two periods, it is possible from this table to determine the reasons for an apparent decline or improvement in a district's position. For example, the significant improvement in Larkana's

${ }^{7}$ For the year 1971-72 the gap, according to mean taxonomic distances, between most and less developed districts emerges as 5.28 and for 1980-81 it comes to 5.75 .

${ }^{8}$ The following specification is used:

$$
\Delta Z_{i j}=\alpha+\beta Z_{i j}
$$

where $Z_{i j}$ is $Z$-score (with two periods being merged into one common data set) of district $i$ for indicator $j$. Positive $\beta$ implies that regional disparity has increased, negative $\beta$ indicates reduced disparity and insignificant refers to the situation where no change in disparity among districts has observed.

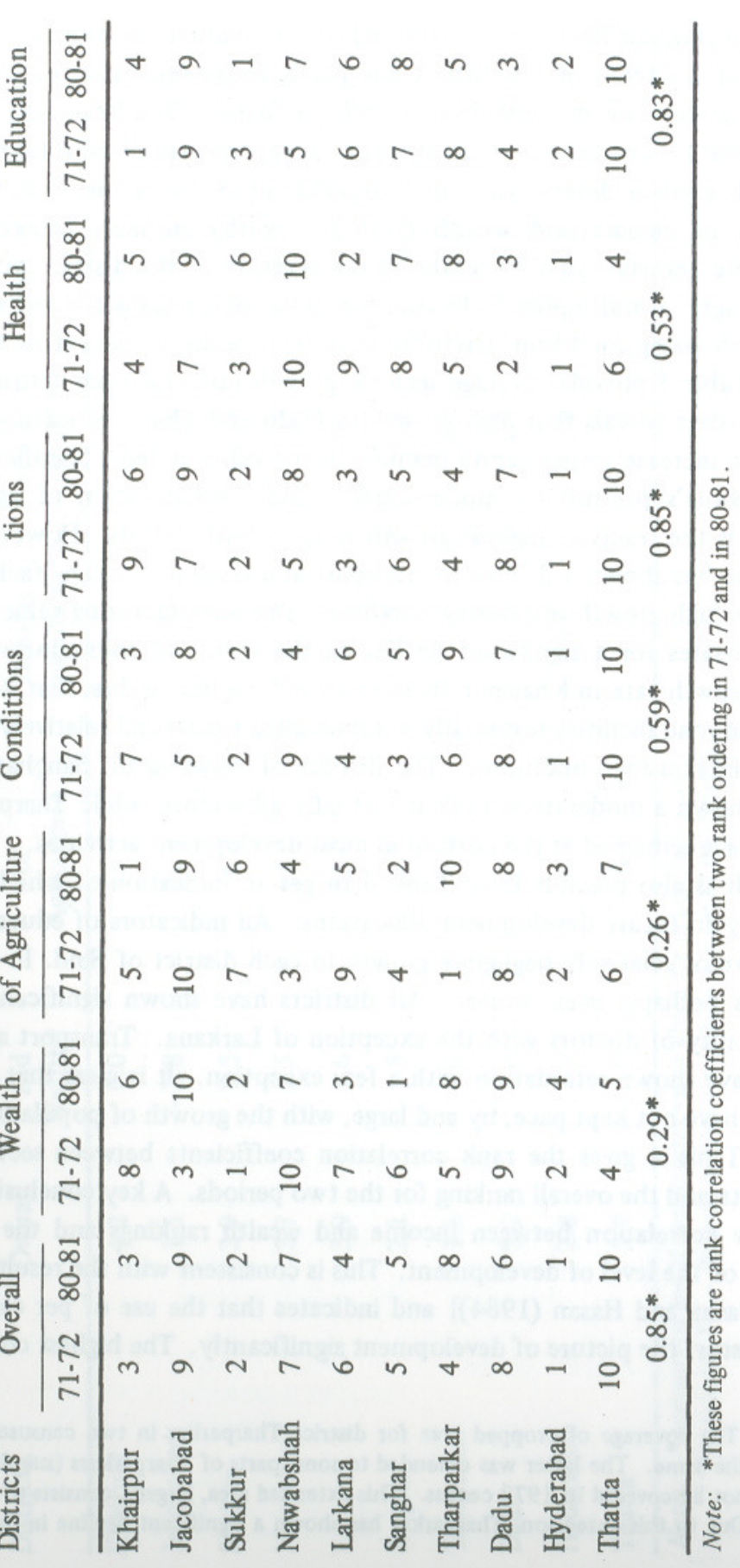


status during the 70 s can be attributed to a dramatic improvement (seventh to third) in the productivity of the district due partly to the rapid pace of mechanization and modernization of its agriculture (ninth to fifth). Simultaneously, there has been considerable expansion in social infrastructure, especially health (ninth to second).

The major deterioration in Tharparkar's position is due, first, to relatively slow growth in income and wealth (fifth to eighth) probably caused largely by the complete reversal (first to tenth) of the position of the district with respect to the use of agricultural inputs. ${ }^{9}$ In addition, Tharparkar has witnessed a worsening of its rank in housing conditions (sixth to ninth) and health services (first to eighth).

Table 3 provides average sectoral growth rates for each district. An examination of data reveals that high growth in Dadu and Thatta is, mainly, because of substantive increase in per capita manufacturing value added. Significant improvement in Larkana's position in modernization and mechanization of agriculture and in health is the result of highest growth rates in both sectors. However, the district of Larkana has shown a decline in transport and communications facilities. In District Sukkur high growth in housing conditions and manufacturing value added per capita compensates for a significant decline in the sector of communications and health. High growth rate in Khairpur district (second highest) is due, first, to major improvement in road facilities (especially in unmetalled roads) and relatively greater improvement in housing conditions. The district of Nawabshah, Sanghar and Hyderabad have shown a moderate growth in virtually all sectors, while Tharparkar and Jacobabad have remained at the bottom in most development activities.

It is also possible from Table 3 to get an indication of which sector demands priority in future development allocations. All indicators of education have shown negative or relatively negligible growth in each district of Sind. In health, the situation is perhaps, even worse. All districts have shown significant declines in the availability of doctors with the exception of Larkana. Transport and road facilities also have shown retardation with a few exception. It is clear that development activities have not kept pace, by and large, with the growth of population.

Table 4 gives the rank correlation coefficients between sectoral ranks of the districts and the overall ranking for the two periods. A key conclusion is the relatively low correlation between income and wealth rankings and the overall status in terms of the level of development. This is consistent with the results of other studies [see Pasha and Hasan (1984)] and indicates that the use of per capita income only can distort the picture of development significantly. The highest correlation with the

${ }^{9}$ The coverage of cropped area for district Tharparkar in two censuses (1972 and 1981) is not the same. The latter was extended to some parts of Tharparkars (sub-division Mithi) which could not be covered in 1972 census. This extended area, largely, consists of unirrigated cropped area. Due to this extension, Tharparkar has shown a significant decline in the extent of irrigated area.

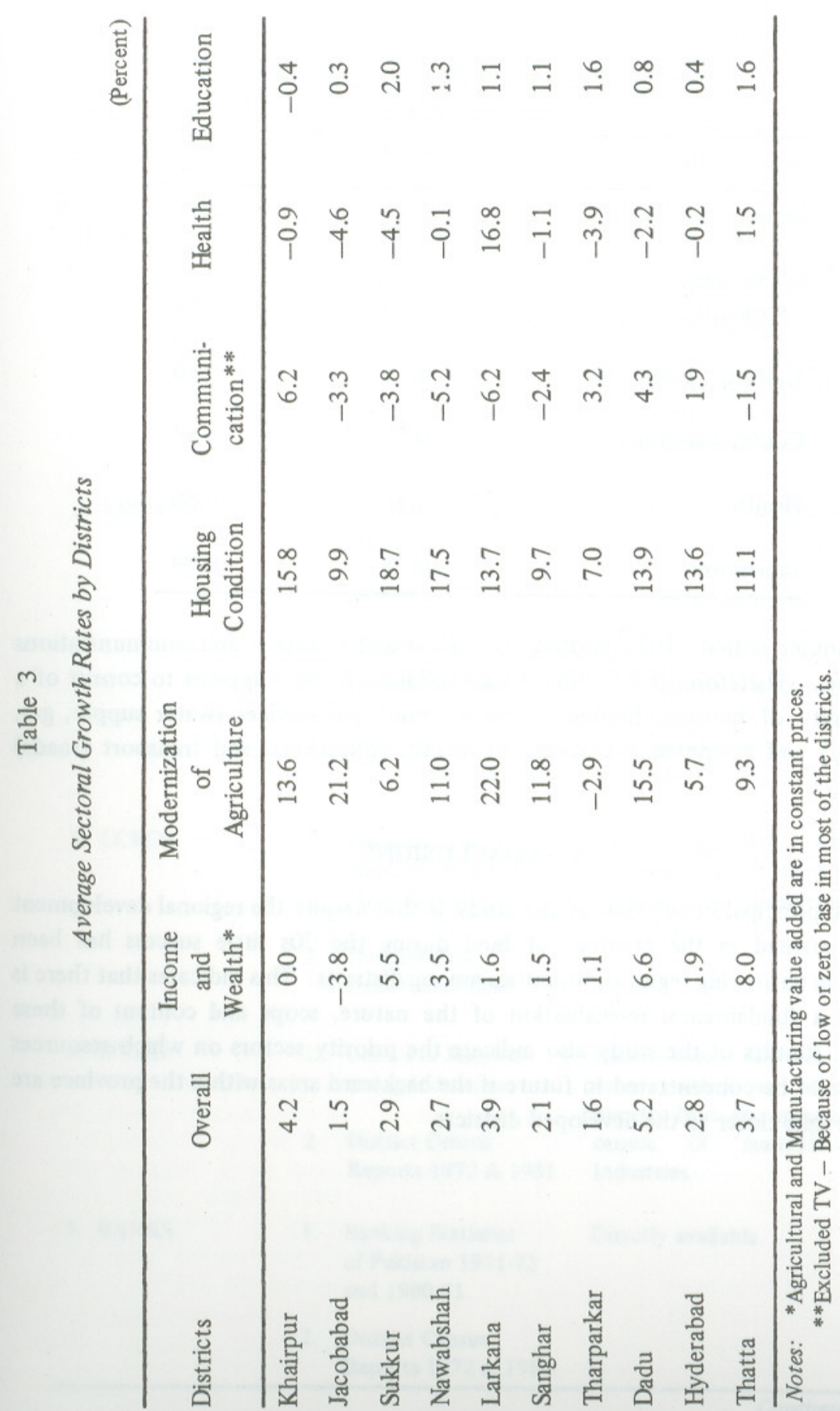


Table 4

Rank Correlation Coefficients between Overall and Sectoral Ranks

\begin{tabular}{lcc}
\hline Sectors & $1971-72$ & $1980-81$ \\
\hline Income and Wealth & 0.32 & 0.58 \\
$\begin{array}{l}\text { Modernization of } \\
\text { Agriculture }\end{array}$ & 0.50 & 0.64 \\
Housing Conditions & 0.71 & 0.90 \\
Communications & 0.67 & 0.83 \\
Health & 0.48 & 0.50 \\
Education & 0.72 & 0.79 \\
\hline
\end{tabular}

overall ranking is that of the housing, education and transport and communications indications. Therefore, the profile of backwardness in Sind appears to consist of a poor quality of housing, limited _. ess to municipal services (water supply, gas, electricity) and restricted availability of health, educational and transport (roads) facilities.

\section{CONCLUSIONS}

The principal conclusion of the study is that despite the regional development policies pursued in the province of Sind during the 70 s little success has been achieved in narrowing regional disparities among districts. This indicates that there is need for a fundamental re-evaluation of the nature, scope and content of these policies. Results of the study also indicate the priority sectors on which resources may have to be concentrated in future if the backward areas within the province are to be brought closer to the developed districts.
Appendix Table A-1

Sources of Data for Development Indicators

\begin{tabular}{lll}
\hline Indicators & Sources & \multicolumn{1}{c}{$\begin{array}{c}\text { Nature of Data } \\
\text { Manipulation }\end{array}$} \\
\hline $\begin{array}{l}\text { Income and Wealth } \\
\text { 1. AGVAD }\end{array}$ & 1. $\begin{array}{l}\text { Development } \\
\text { Statistics of Sind }\end{array}$ & $\begin{array}{l}\text { For detailed discussion of es- } \\
\text { timation procedure and com- } \\
\text { putational framework, see } \\
\text { "Regional Accounts of Sind } \\
\text { 2. Markets and Prices }\end{array}$ \\
3. District Census & $\begin{array}{l}\text { 1970-71 to 1979-80" by } \\
\text { Nuzhat Ahmad and Haroon } \\
\text { Jamal, Applied Economics Re- } \\
\text { search Centre (Unpublished). }\end{array}$ \\
&
\end{tabular}

2. LSTOCK

3. CCROP

4. MVAD

5. BANKS
1. Pakistan Census of Agriculture (Province Reports), 1972 and 1980

2. Development Statistics of Sind

3. District Census Reports 1972 \& 1981

1. Pakistan Census of Agriculture (Province Reports)

2. Development Statistics of Sind

1. Census of Manufacturing Industries

2. District Census Reports 1972 \& 1981

1. Banking Statistics of Pakistan 1971-72 and $1980-81$

2. District Census
This indicator is constructed using the method adopted in Pasha and Hasan (1982). The weights assigned to each category of livestock are as follows:

Buffalo Cow \& Camel 1.0

Cattle

Poultry

Rice, Sugar-cane, Cotton Rapeseed \& Mustard and Tobacco are considered as cash crops.

District-wise manufacturing value added is obtained directly from the appropriate census of manufacturing Industries.

Directly available. 


\begin{tabular}{|c|c|c|}
\hline Indicators & Sources & $\begin{array}{l}\text { Nature of Data } \\
\text { Manipulation }\end{array}$ \\
\hline
\end{tabular}

\section{Modernization of}

Agriculture
6. IRRI
7. FERT

8. TRACT 1. Development
Statistics of Sind

2. Pakistan Census of

Agriculture (Pro-

vince Reports)

\section{Housing Conditions}

9. ELECT

1. Pasha and Hasan (1984)

10. WATER

11. GAS 2. District-wise Housing for the year 1980-81 in dis-

Direct district-wise data on for the year 1980-81 in district-wise Housing Census reports but an estimate was needed for the year 1971-72. Fortunately Pasha and Hasan (1984) estimated using Population Census figures of 1971-72 and Housing, Economic and Demographic Survey, 1973. For detail see Pasha and Hasan (1984, p. 186).

Communications

\section{RADIO}

13. TV

1. Development Statistics of Sind

14. POST

15. TELEP

1. Pasha and Hasan (1984)

2. District-wise Census Reports, 1972 and 1981

The direct data on number of residential telephone connections were not available, hence an estimate was needed. For the year 1971-72 the related figure were obtained from Pasha and Hasan (1984, p. 190). District-wise Census reports of 1981 provide the total number of telephone connections including manufacturing concerns,
Appendix Table A-1 - (Continued)

therefore, to avoid double counting, these figures were adjusted by allowing 5 to 10 percent deduction, keeping manufacturing value added of districts in view.

\begin{tabular}{|c|c|c|c|}
\hline $\begin{array}{l}\text { 16. MROAD } \\
\text { 17. UMROAD }\end{array}$ & 1. & $\begin{array}{l}\text { District-wise Census } \\
\text { Reports, } 1972 \text { and } 1981\end{array}$ & Directly available. \\
\hline 18. PASSEN & 1. & $\begin{array}{l}\text { Development Stat- } \\
\text { istics of Sind }\end{array}$ & Directly available. \\
\hline 19. CARS & 2. & $\begin{array}{l}\text { District-wise Census } \\
\text { Reports }\end{array}$ & \\
\hline
\end{tabular}

20. BEDS

Development Statistics of Sind

Directly available.

2. District-wise Census Reports

21. DOCTORS

1. Pasha and Hasan (1984)

2. District-wise Census Reports

Education

22. PENR

23. MENR

24. HENR

25. IDENR

26. PTSC

27. PTST

28. HTSC

29. HTST

30. IDTSC
1. Development Statistics of Sind

2. District-wise Census Reports
No published data on number of doctors are available. For the year 1971-72 number of doctors per 10,000 of population was obtained from Pasha and Hasan (1984). Districtwise number of doctors for the year 1982 are available in an unpublished paper by $\mathrm{N}$. A. Abbasi "An Analytical Evaluation of Personal Health Care Services, Organization Regional Plan Organization". Karachi, 1983.

All data are obtained direct ly. Enrollment ratio are calculated as percentage of the following age groups: 5-9 years for PENR 10-14 years for MENR 15-19 years for HENR 20-24 years for IDENR and Management: Sind 
Appendix Table A-2

Taxonomic Distance by Districts

Khairpur Jacobabad Sukkur Nawabshah Larkana Sanghar Tharparkar Dadu Hyderabad Thatta

\begin{tabular}{|c|c|c|c|c|c|c|c|c|c|c|c|}
\hline \multirow[t]{2}{*}{ Total } & $1971-72$ & 12.72 & 14.37 & 10.89 & 13.70 & 13.42 & 13.26 & 13.12 & 13.79 & 8.08 & 15.15 \\
\hline & $1980-81$ & 12.40 & 15.13 & 10.74 & 13.60 & 12.73 & 13.00 & 14.14 & 13.50 & 8.11 & 15.30 \\
\hline \multirow{2}{*}{$\begin{array}{l}\text { Income and } \\
\text { Wealth }\end{array}$} & $1971-72$ & 4.87 & 3.04 & 2.82 & 5.18 & 4.35 & 3.58 & 3.48 & 5.17 & 3.04 & 3.38 \\
\hline & $1980-81$ & 4.73 & 5.65 & 4.59 & 5.32 & 4.64 & 3.68 & 5.39 & 5.52 & 4.69 & 4.72 \\
\hline \multirow{2}{*}{$\begin{array}{l}\text { Modernization } \\
\text { of Agriculture }\end{array}$} & $1971-72$ & 2.31 & 4.79 & 3.45 & 2.11 & 4.34 & 2.30 & 0.54 & 3.95 & 0.86 & 2.94 \\
\hline & $1980-81$ & 1.25 & 4.15 & 3.60 & 2.33 & 3.30 & 2.09 & 5.03 & 4.14 & 2.13 & 3.82 \\
\hline \multirow{2}{*}{$\begin{array}{l}\text { Housing } \\
\text { Conditions }\end{array}$} & $1971-72$ & 5.38 & 5.28 & 3.23 & 5.60 & 5.12 & 4.16 & 5.28 & 5.56 & 0.0 & 6.15 \\
\hline & $1980-81$ & 4.57 & 5.02 & 2.05 & 4.58 & 4.70 & 4.59 & 5.40 & 4.99 & 0.47 & 5.84 \\
\hline \multirow{2}{*}{$\begin{array}{l}\text { Communi- } \\
\text { cations }\end{array}$} & $1971-72$ & 7.62 & 7.56 & 5.30 & 7.10 & 6.30 & 7.50 & 6.90 & 7.50 & 3.90 & 8.30 \\
\hline & $1980-81$ & 6.80 & 7.70 & 5.00 & 7.30 & 6.50 & 6.76 & 6.70 & 7.20 & 2.10 & 8.60 \\
\hline \multirow[t]{2}{*}{ Health } & $1971-72$ & 3.98 & 4.24 & 3.75 & 4.71 & 4.70 & 4.48 & 4.14 & 3.27 & 0.0 & 4.23 \\
\hline & $1980-81$ & 4.08 & 4.53 & 4.26 & 4.55 & 2.98 & 4.46 & 4.48 & 3.54 & 0.0 & 3.57 \\
\hline \multirow[t]{2}{*}{ Education } & $1971-72$ & 5.48 & 8.34 & 6.78 & 7.22 & 7.36 & 8.02 & 8.23 & 6.97 & 6.33 & 8.81 \\
\hline & $1980-81$ & 6.86 & 8.45 & 5.85 & 7.58 & 7.35 & 7.97 & 7.12 & 6.70 & 5.88 & 8.59 \\
\hline
\end{tabular}

Appendix Table A-3

Z-sum Score by Districts

Khairpur Jacobabad Sukkur Nawabshah Larkana Sanghar Tharparkar Dadu Hyderabad Thatta

\begin{tabular}{|c|c|c|c|c|c|c|c|c|c|c|c|}
\hline Total & $\begin{array}{l}1971-72 \\
1980-81\end{array}$ & $\begin{array}{l}2.19 \\
2.68\end{array}$ & $\begin{array}{l}-10.65 \\
-16.77\end{array}$ & $\begin{array}{l}10.72 \\
15.06\end{array}$ & $\begin{array}{l}-7.78 \\
-5.94\end{array}$ & $\begin{array}{l}-6.51 \\
-1.56\end{array}$ & $\begin{array}{r}-4.21 \\
0.04\end{array}$ & $\begin{array}{r}3.35 \\
-9.05\end{array}$ & $\begin{array}{l}-8.30 \\
-6.54\end{array}$ & $\begin{array}{l}35.23 \\
34.68\end{array}$ & $\begin{array}{l}-14.04 \\
-12.60\end{array}$ \\
\hline $\begin{array}{l}\text { Income and } \\
\text { Wealth }\end{array}$ & $\begin{array}{l}1971-72 \\
1980-81\end{array}$ & $\begin{array}{r}-1.12 \\
0.04\end{array}$ & $\begin{array}{r}3.11 \\
-2.26\end{array}$ & $\begin{array}{l}1.71 \\
1.53\end{array}$ & $\begin{array}{l}-3.38 \\
-1.78\end{array}$ & $\begin{array}{l}-1.69 \\
-0.17\end{array}$ & $\begin{array}{l}0.74 \\
3.07\end{array}$ & $\begin{array}{r}1.95 \\
-0.66\end{array}$ & $\begin{array}{l}-2.92 \\
-1.26\end{array}$ & $\begin{array}{l}2.42 \\
0.79\end{array}$ & $\begin{array}{r}-0.83 \\
0.69\end{array}$ \\
\hline $\begin{array}{l}\text { Modernization } \\
\text { of Agriculture }\end{array}$ & $\begin{array}{l}1971-72 \\
1980-81\end{array}$ & $\begin{array}{l}1.15 \\
3.48\end{array}$ & $\begin{array}{l}-4.28 \\
-2.26\end{array}$ & $\begin{array}{l}-1.49 \\
-0.47\end{array}$ & $\begin{array}{l}1.44 \\
2.40\end{array}$ & $\begin{array}{l}-3.12 \\
-0.79\end{array}$ & $\begin{array}{l}1.44 \\
2.34\end{array}$ & $\begin{array}{r}3.76 \\
-3.47\end{array}$ & $\begin{array}{l}-2.34 \\
-1.88\end{array}$ & $\begin{array}{c}3.21 \\
-1.62\end{array}$ & $\begin{array}{r}0.25 \\
-0.96\end{array}$ \\
\hline $\begin{array}{l}\text { Housing } \\
\text { Conditions }\end{array}$ & $\begin{array}{l}1971-72 \\
1980-81\end{array}$ & $\begin{array}{l}-1.42 \\
-0.70\end{array}$ & $\begin{array}{l}-1.23 \\
-1.47\end{array}$ & $\begin{array}{l}2.35 \\
4.40\end{array}$ & $\begin{array}{l}-1.79 \\
-0.74\end{array}$ & $\begin{array}{l}-0.95 \\
-0.86\end{array}$ & $\begin{array}{r}0.84 \\
-0.77\end{array}$ & $\begin{array}{l}-1.22 \\
-2.18\end{array}$ & $\begin{array}{l}-1.73 \\
-1.43\end{array}$ & $\begin{array}{l}7.90 \\
6.70\end{array}$ & $\begin{array}{l}-2.75 \\
-2.94\end{array}$ \\
\hline $\begin{array}{l}\text { Communica- } \\
\text { tions }\end{array}$ & $\begin{array}{l}1971-72 \\
1980-81\end{array}$ & $\begin{array}{l}-3.31 \\
-1.2\end{array}$ & $\begin{array}{l}-2.4 \\
-5.1\end{array}$ & $\begin{array}{l}5.6 \\
4.4\end{array}$ & $\begin{array}{l}-1.5 \\
-1.9\end{array}$ & $\begin{array}{l}.6 \\
.2\end{array}$ & $\begin{array}{l}-3.14 \\
-.03\end{array}$ & $\begin{array}{r}2.4 \\
-.9\end{array}$ & $\begin{array}{l}-3.1 \\
-2.3\end{array}$ & $\begin{array}{l}11.0 \\
13.7\end{array}$ & $\begin{array}{l}-5.8 \\
-6.9\end{array}$ \\
\hline Health & $\begin{array}{l}1971-72 \\
1980-81\end{array}$ & $\begin{array}{l}-0.32 \\
-0.62\end{array}$ & $\begin{array}{l}-0.74 \\
-1.22\end{array}$ & $\begin{array}{l}-0.01 \\
-0.89\end{array}$ & $\begin{array}{l}-1.41 \\
-1.27\end{array}$ & $\begin{array}{r}-1.32 \\
1.41\end{array}$ & $\begin{array}{l}-1.08 \\
-1.17\end{array}$ & $\begin{array}{l}-0.52 \\
-1.22\end{array}$ & $\begin{array}{l}9.88 \\
0.28\end{array}$ & $\begin{array}{l}5.25 \\
5.12\end{array}$ & $\begin{array}{l}-0.72 \\
-0.42\end{array}$ \\
\hline Education & $\begin{array}{l}1971-72 \\
1980-81\end{array}$ & $\begin{array}{l}7.21 \\
1.72\end{array}$ & $\begin{array}{l}-5.09 \\
-4.46\end{array}$ & $\begin{array}{l}2.62 \\
6.11\end{array}$ & $\begin{array}{l}-1.09 \\
-2.66\end{array}$ & $\begin{array}{l}-0.05 \\
-1.36\end{array}$ & $\begin{array}{l}-2.81 \\
-3.45\end{array}$ & $\begin{array}{l}-3.01 \\
-0.64\end{array}$ & $\begin{array}{l}0.95 \\
0.06\end{array}$ & $\begin{array}{l}5.48 \\
6.74\end{array}$ & $\begin{array}{r}-4.22 \\
2.06\end{array}$ \\
\hline
\end{tabular}


Appendix Table A-4

Mean and-Standard Deviation of Development Indicators

Indicators

1971-72

$1980-81$

I. Income and Wealth
1. AGVAD

$\begin{array}{lc}331.00 & 834.33 \\ (75.80) & (355.88)\end{array}$
(Agricultural Value Added in Constant
$(75.80)$
$(355.88)$
Rupees per Rural Person)
2. $\mathrm{LSTOCK}$

$0.50 \quad 0.43$
(Equivalent Number of Livestock per Rural
$(0.07)$
Person)
3. CCROP
[Extent of Commercialization of
35.87
42.20
Agriculture (Percent)]
4. MVAD
(Manufacturing Value Added in Constant Rupees per Capita-Urban)

$\begin{array}{cc}230.68 & 1861.18 \\ (107.31) & (2133.70)\end{array}$

$\begin{array}{cc}3.11 & 5.77 \\ (0.68) & (0.96)\end{array}$
5. BANKS
(Bank Branches per 100 Thousand of Population)

\section{Modernization of Agriculture}

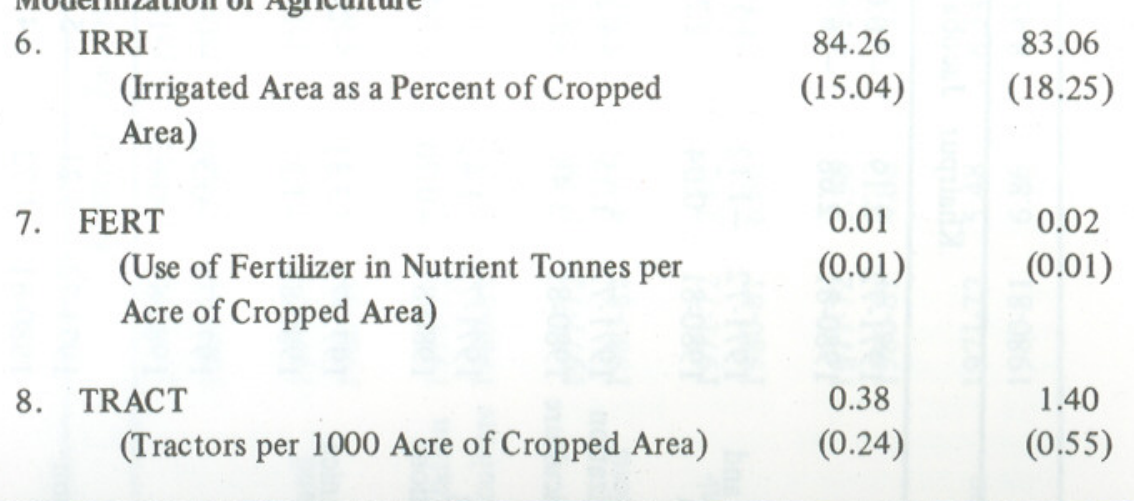

Appendix Table A-4 - (Continued)

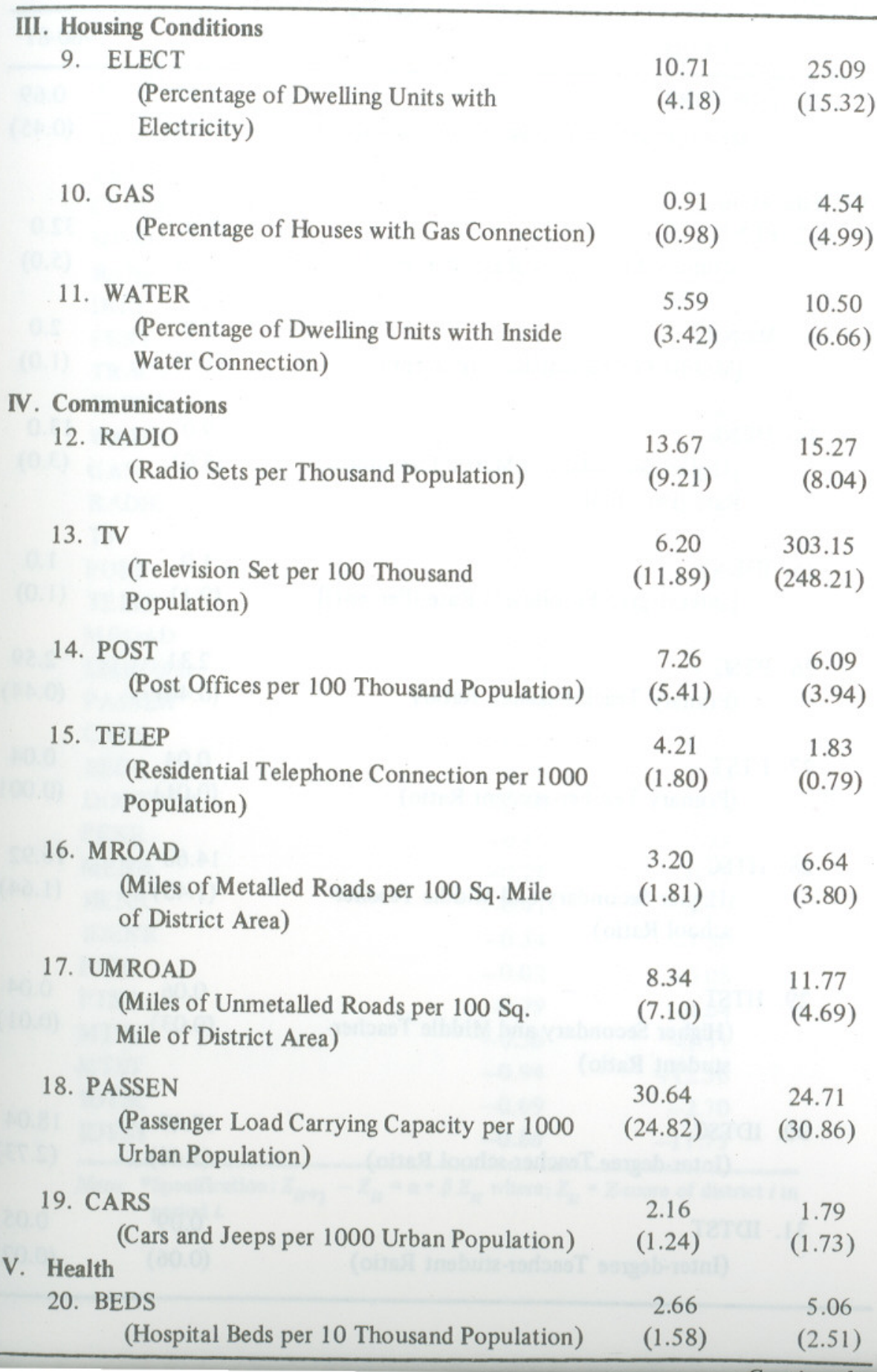


Appendix Table A-4 - (Continued)

\begin{tabular}{|c|c|c|}
\hline Indicators & $1971-72$ & $1980-81$ \\
\hline $\begin{array}{l}\text { 21. DOCTORS } \\
\text { (Doctors per } 10 \text { Thousand Population) }\end{array}$ & $\begin{array}{l}1.01 \\
(0.58)\end{array}$ & $\begin{array}{l}0.69 \\
(0.45)\end{array}$ \\
\hline $\begin{array}{l}\text { VI. Education } \\
\text { 22. PENR } \\
\text { [Primary Enrollment Rate (Percent)] }\end{array}$ & $\begin{array}{l}35.0 \\
(8.0)\end{array}$ & $\begin{array}{l}32.0 \\
(5.0)\end{array}$ \\
\hline $\begin{array}{l}\text { 23. MENR } \\
\text { [Middle Enrollment Rate (Percent)] }\end{array}$ & $\begin{array}{c}2.0 \\
(1.0)\end{array}$ & $\begin{array}{l}2.0 \\
(1.0)\end{array}$ \\
\hline $\begin{array}{l}\text { 24. HENR } \\
\text { [Higher Secondary or Matric Enrollment } \\
\text { Rate (Percent)] }\end{array}$ & $\begin{array}{l}9.0 \\
(3.0)\end{array}$ & $\begin{array}{l}13.0 \\
(3.0)\end{array}$ \\
\hline $\begin{array}{l}\text { 25. IDENR } \\
\text { [Inter-degree Enrollment Rate (Percent)] }\end{array}$ & $\begin{array}{c}1.0 \\
(0.1)\end{array}$ & $\begin{array}{c}1.0 \\
(1.0)\end{array}$ \\
\hline $\begin{array}{l}\text { 26. PTSC } \\
\text { (Primary Teacher-school Ratio) }\end{array}$ & $\begin{array}{c}2.31 \\
(0.40)\end{array}$ & $\begin{array}{c}2.59 \\
(0.44)\end{array}$ \\
\hline $\begin{array}{l}\text { 27. PTST } \\
\text { (Primary Teacher-student Ratio) }\end{array}$ & $\begin{array}{c}0.04 \\
(0.01)\end{array}$ & $\begin{array}{c}0.04 \\
(0.001)\end{array}$ \\
\hline $\begin{array}{l}\text { 28. HTSC } \\
\text { (Higher Secondary and Middle Teacher- } \\
\text { school Ratio) }\end{array}$ & $\begin{array}{l}14.60 \\
(1.45)\end{array}$ & $\begin{array}{l}16.92 \\
(1.64)\end{array}$ \\
\hline $\begin{array}{l}\text { 29. HTST } \\
\text { (Higher Secondary and Middle Teacher- } \\
\text { student Ratio) }\end{array}$ & $\begin{array}{c}0.06 \\
(0.03)\end{array}$ & $\begin{array}{l}0.04 \\
(0.01)\end{array}$ \\
\hline $\begin{array}{l}\text { 30. IDTSC } \\
\text { (Inter-degree Teacher-school Ratio) }\end{array}$ & $\begin{array}{l}17.49 \\
(3.46)\end{array}$ & $\begin{array}{l}18.04 \\
(2.73)\end{array}$ \\
\hline $\begin{array}{l}\text { 31. IDTST } \\
\text { (Inter-degree Teacher-student Ratio) }\end{array}$ & $\begin{array}{l}0.09 \\
(0.06)\end{array}$ & $\begin{array}{c}0.05 \\
(0.02)\end{array}$ \\
\hline
\end{tabular}

Appendix Table A-5

Results of Regression Analysis*

\begin{tabular}{|c|c|c|}
\hline Indicators & $\beta$-Coefficient & $t$-Statistics \\
\hline AGVAD & 0.15 & 0.09 \\
\hline LSTOCK & -0.92 & -2.86 \\
\hline CCROP & -0.68 & -1.12 \\
\hline MVAD & 7.06 & 1.09 \\
\hline BANKS & -0.72 & -1.49 \\
\hline IRRI & -0.65 & -1.58 \\
\hline FERT & 0.23 & 0.85 \\
\hline TRACT & -0.59 & -0.74 \\
\hline ELECT & 1.92 & 2.46 \\
\hline WATER & 0.88 & 4.93 \\
\hline GAS & 3.90 & 7.75 \\
\hline RADIO & -0.46 & -1.89 \\
\hline TV & 16.04 & 3.76 \\
\hline POST & -1.16 & -4.63 \\
\hline TELEP & -0.62 & -7.93 \\
\hline MROAD & 0.43 & 0.79 \\
\hline UMROAD & -0.73 & -3.43 \\
\hline PASSEN & -0.23 & -0.67 \\
\hline CARS & -0.31 & -0.73 \\
\hline BEDS & 0.28 & 0.84 \\
\hline DOCTORS & -0.30 & -2.58 \\
\hline PENR & -0.46 & -2.88 \\
\hline MENR & -0.25 & -0.82 \\
\hline HENR & -0.41 & -1.57 \\
\hline IDENR & -0.34 & -1.50 \\
\hline PTSC & -0.02 & -0.08 \\
\hline PTST & -0.79 & -4.64 \\
\hline MTSC & -0.56 & -1.51 \\
\hline MTST & -0.94 & -12.36 \\
\hline IDTSC & -0.69 & -2.70 \\
\hline IDTST & -0.86 & -11.75 \\
\hline
\end{tabular}

Note: ${ }^{*}$ Specification: $Z_{i t+1}-Z_{i t}=\alpha+\beta Z_{i t}$ where; $Z_{i t}=Z$-score of district $i$ in period $t$. 
Appendix Table A-6

Magnitude of Development Indicators for Districts of Sind *

\begin{tabular}{|c|c|c|c|c|c|c|c|c|c|c|}
\hline & Khairpur & Jacobabad & Sukkur & Nawabshah & Larkana & Sanghar & Tharparkar & Dadu & Hyderabad & Thatta \\
\hline \multicolumn{11}{|c|}{$1971-72$} \\
\hline AGVAD & 342.870 & 459.850 & 383.630 & 220.020 & 326.650 & 321.400 & 422.220 & 209.040 & 340.570 & 283.770 \\
\hline LSTOCK & 0.590 & 0.620 & 0.510 & 0.420 & 0.490 & 0.580 & 0.380 & 0.480 & 0.460 & 0.450 \\
\hline CCROP & 21.910 & 37.260 & 34.080 & 33.940 & 41.370 & 35.320 & 41.020 & 28.610 & 38.140 & 47.080 \\
\hline MVAD & 321.160 & 70.000 & 275.800 & 253.100 & 62.000 & 91.100 & 327.300 & 308.300 & 353.700 & 244.500 \\
\hline BANKS & 2.250 & 3.810 & 3.540 & 2.580 & 2.600 & 3.900 & 3.540 & 2.610 & 4.030 & 2.200 \\
\hline IRRI & 98.240 & 51670 & 77.920 & 96.270 & 67.640 & 97.980 & 98.160 & 75.990 & 93.910 & 84.830 \\
\hline FERT & 0.010 & 0.001 & 0.004 & 0.020 & 0.004 & 0.020 & 0.023 & 0.004 & 0.020 & 0.002 \\
\hline TRACT & 0.490 & 0.130 & 0.320 & 0.310 & 0.070 & 0.240 & 0.640 & 0.140 & 0.770 & 0.680 \\
\hline ELECT & 8.500 & 9.100 & 14.500 & 8.000 & 9.600 & 13.700 & 9.200 & 7.600 & 20.800 & 6.100 \\
\hline WATER & 4.000 & 4.100 & 8.000 & 3.500 & 4.600 & 6.300 & 4.100 & 3.600 & 14.900 & 2.800 \\
\hline GAS & 0.500 & 0.510 & 1.630 & 0.390 & 0.530 & 0.830 & 0.500 & 0.520 & 3.610 & 0.100 \\
\hline RADIO & 16.001 & 9.200 & 16.964 & 6.998 & 12.052 & 5.560 & 33.744 & 7.766 & 25.645 & 2.761 \\
\hline TV & 0.000 & 0.000 & 0.070 & 0.590 & 0.000 & 1.590 & 5.710 & 2.730 & 40.470 & 10.830 \\
\hline POST & 8.080 & 2.120 & 21.810 & 5.980 & 6.510 & 9.380 & 2.850 & 8.440 & 2.930 & 4.540 \\
\hline TELEP & 3.500 & 2.500 & 7.500 & 3.300 & 4.000 & 2.800 & 3.700 & 5.500 & 7.200 & 2.100 \\
\hline MROAD & 1.620 & 3.080 & 2.310 & 3.430 & 3.900 & 4.690 & 0.900 & 1.980 & 7.590 & 2.470 \\
\hline UMROAD & 0.640 & 5.120 & 10.970 & 17.630 & 15.000 & 2.440 & 0.500 & 8.850 & 20.700 & 1.490 \\
\hline PASSEN & 5.350 & 23.650 & 48.450 & 19.300 & 39.740 & 17.480 & 86.790 & 3.800 & 52.140 & 9.750 \\
\hline CARS & 2.370 & 3.740 & 2.900 & 1.420 & 1.990 & 0.740 & 3.980 & 0.350 & 3.260 & 0.810 \\
\hline BEDS & 2.890 & 2.200 & 1.960 & 1.280 & 2.230 & 1.410 & 1310 & 4.370 & 6.620 & 2.310 \\
\hline DOCTORS & 0.740 & 0.750 & 1.260 & 0.700 & 0.400 & 0.840 & 1.200 & 0.890 & 2.590 & 0.720 \\
\hline PENR & 40.000 & 31.000 & 49.000 & 27.000 & 40.000 & 37.000 & 23.000 & 40.000 & 36.000 & 24.000 \\
\hline MENR & 4.000 & 2000 & 2.000 & 2.000 & 2.000 & 1.000 & 2.000 & 1.000 & 3.000 & 1.000 \\
\hline HENR & 11.000 & 7.000 & 4.000 & 8.000 & 10.000 & 13.000 & 9.000 & 8.000 & 14.000 & 3.000 \\
\hline IDENR & 1.000 & 0.300 & 1.000 & -1.000 & 0.200 & 1.000 & 1.000 & 1.000 & 2.000 & 0.100 \\
\hline PTSC & 2.650 & 2.130 & 2.560 & 2.570 & 2.160 & 2.120 & 1.600 & 2.440 & 3.020 & 1.840 \\
\hline PTST & 0.050 & 0.030 & 0.030 & 0.040 & 0.040 & 0.040 & 0.060 & 0.040 & 0.040 & 0.050 \\
\hline HISC & 18.290 & 13.930 & 15.160 & 15.790 & 14.590 & 13.790 & 13.370 & 14.250 & 13.430 & 13.360 \\
\hline HTST & 0.050 & 0.060 & 0.140 & 0.050 & 0.040 & 0.050 & 0.050 & 0.050 & 0.050 & 0.090 \\
\hline IDTSC & 14.800 & 13.330 & 18.000 & 17.000 & 17.330 & 13.250 & 17.600 & 24.670 & 22.400 & 16.500 \\
\hline IDTST & 0.050 & 0.080 & 0.080 & 0.040 & 0.220 & 0,040 & 0.060 & 0.070 & 0.060 & 0.220 \\
\hline
\end{tabular}

\begin{tabular}{|c|c|c|c|c|c|c|c|c|c|c|}
\hline \multicolumn{11}{|c|}{$1980-81$} \\
\hline AGVAD & 994.120 & 1119.270 & 425.070 & 741.460 & 856.490 & 1701.980 & 782.710 & 530.760 & 699.790 & 491.670 \\
\hline LSTOCK & 0.520 & 0.420 & 0.430 & 0.360 & 0.420 & 0.480 & 0.570 & 0.350 & 0370 & 0.420 \\
\hline CCROP & 27.700 & 44.660 & 62.210 & 39.240 & 50.580 & 40.480 & 18.000 & 43.450 & 50.400 & 45.240 \\
\hline MVAD & 339.900 & 52.300 & 2041.800 & 1125.900 & 142.600 & 195.800 & 1335.800 & 5637.100 & 1521.300 & 6219.100 \\
\hline BANKS & 6.010 & 3.660 & 6.620 & 5.990 & 5.780 & 6.620 & 5.590 & 4.830 & 7.200 & 5.350 \\
\hline IRRI & 99.080 & 68.790 & 84.830 & 99.060 & 77.070 & 99.910 & 39.090 & 73.690 & 96.160 & 92.930 \\
\hline FERT & 0.030 & 0.010 & 0.002 & 0.040 & 0.020 & 0.040 & 0.030 & 0.020 & 0.030 & 0.010 \\
\hline TRACT & 2.600 & 1.050 & 2.000 & 1.320 & 1.340 & 1.470 & 0.680 & 0.690 & 1.640 & 1.250 \\
\hline ELECT & 23.000 & 20.450 & 57.220 & 20.680 & 24.930 & 18.990 & 11.270 & 18.620 & 50.040 & 5.670 \\
\hline WATER & 9.300 & 7.070 & 16.120 & 10.390 & 7.280 & 9.450 & 6.260 & 6.350 & 28.260 & 4.470 \\
\hline GAS & 2.610 & 1.270 & 11.810 & 2.360 & 2.700 & 3.480 & 1.320 & 2.620 & 16.520 & 0.730 \\
\hline RADIO & 14.165 & 10.726 & 29.200 & 6.175 & 11.264 & 17.796 & 18.031 & 6.896 & 29.656 & 8.787 \\
\hline TV & 115.270 & 146.440 & 497.730 & 203.600 & 297.200 & 285.140 & 202.600 & 202.040 & 973.650 & 107.760 \\
\hline POST & 2.240 & 1.380 & 1.220 & 3.540 & 11.310 & 9.110 & 10.320 & 11.520 & 3.990 & 6.290 \\
\hline TELEP & 1.540 & 1.280 & 2.840 & 1.470 & 1.960 & 1.620 & 1.570 & 1.440 & 3.720 & 0.890 \\
\hline MROAD & 10.290 & 4.050 & 4.870 & 10.910 & 8.580 & 5.690 & 1.270 & 3.170 & 13.730 & 3.900 \\
\hline UMROAD & 14.130 & 7.490 & 16.200 & 16.680 & 12.830 & 17.800 & 8.380 & 8.590 & 13.390 & 2.240 \\
\hline PASSEN & 7.150 & 13.920 & 42.960 & 5.770 & 3.440 & 0.830 & 47.110 & 20.640 & 104.140 & 1.160 \\
\hline CARS & 1.980 & 1.690 & 3.090 & 0.400 & 0.400 & 0.120 & 1.510 & 1.750 & 6.270 & 0.660 \\
\hline BEDS & 4.260 & 3.820 & 2.470 & 3.640 & 8.510 & 3390 & 2.860 & 6.210 & 10.660 & 4.810 \\
\hline DOCTORS & 0.560 & 0.370 & 0.760 & 0.380 & 0.710 & 0.470 & 0.540 & 0.610 & 1.980 & 0.550 \\
\hline PENR & 37.000 & 20.000 & 39.000 & 30.000 & 35.000 & 34.000 & 28.000 & 34.000 & 36.000 & 26.000 \\
\hline MENR & 5.000 & 2.000 & 2.000 & 3.000 & 2.000 & 2.000 & 3.000 & 3.000 & 2.000 & 1.000 \\
\hline HENR & 13.000 & 9.000 & 16.000 & 12.000 & 15.000 & 15.000 & 12.000 & 11.000 & 18.000 & 7.000 \\
\hline IDENR & 1.000 & 1.000 & 2.000 & 1.000 & 1.000 & 1.000 & 1.000 & 1.000 & 2.000 & 0.300 \\
\hline PTSC & 2.460 & 2.300 & 3.020 & 2.770 & 2.560 & 2.370 & 2.040 & 2.730 & 3.590 & 2.100 \\
\hline PTST & 0.040 & 0.040 & 0.030 & 0.030 & 0.040 & 0.040 & 0.040 & 0.040 & 0.030 & 0.040 \\
\hline HTSC & 18.400 & 17.440 & 19.370 & 16.660 & 16.590 & 14.790 & 17.000 & 16.000 & 19.010 & 14.000 \\
\hline HTST & 0.040 & 0.050 & 0.040 & 0.040 & 0.040 & 0.040 & 0.040 & 0.040 & 0.040 & 0.060 \\
\hline IDTSC & 14.670 & 14.600 & 23.800 & 18.750 & 15.800 & 17.000 & 21.000 & 17.670 & 19.600 & 17.500 \\
\hline IDTST & 0.040 & 0.070 & 0.040 & 0.040 & 0.050 & 0.050 & 0.050 & 0.070 & 0.040 & 0.090 \\
\hline
\end{tabular}

Note: *Excluding Karachi. 


\section{REFERENCES}

Adelman, Irma, and C. T. Morris (1972). "The Measurement of Institutional Characteristics of Nations: Methodological Considerations". The Journal of Development Studies. Vol. 8, No. 3.

Bum, B. (1982). "Factor Analysis and Development: A Note". Journal of Development Economics. Vol. 11, No. 1.

Helbock R.W., and S. H. H. Naqavi (1976). "Inter District Variation in Social Well-being in Pakistan”. Islamabad: Pakistan Institute of Development Economics. (Unpublished Paper)

Khan M. H., and J. A. Zerby (1981). "The Socio-economic Position of Pakistan in the Third World". Pakistan Development Review. Vol. XXI, No. 3.

Khan M. H., and M. Iqbal (1982). "Socio-economic Indicators in Rural Pakistan: Some Evidence". Pakistan Development Review. Vol. XXI, No. 3.

Pasha, Hafiz A., and Tariq Hasan (1984). "Development Ranking of Districts of Pakistan". Pakistan Journal of Applied Economics. Vol. II, No. 2.

Torgerson, Warrven S. (1958). Theory and Methods of Scaling. Charlotte, NC: UMI Publications Ltd.

Zerby, J. A., and M. H. Khan (1984). "A Comparison of Multivariate Methods for Indexing Socio-economic Development”. The Singapore Economic Review. Vol. 29 , No. 1. 